\title{
Evaluation of Systems for Timing of Fungicide Sprays for Control of Postbloom Fruit Drop of Citrus in Brazil
}

\author{
N. A. R. Peres, Former Ph.D. student, N. L. Souza, Professor, and E. L. Furtado, Professor, Universidade Estadual \\ Paulista, FCA, Botucatu, SP, 18603-970, Brazil; and L. W. Timmer, Professor, University of Florida, Citrus Re- \\ search and Education Center, Lake Alfred 33850
}

\begin{abstract}
Peres, N. A. R., Souza, N. L., Furtado, E. L., and Timmer, L. W. 2004. Evaluation of systems for timing of fungicide sprays for control of postbloom fruit drop of citrus in Brazil. Plant Dis. $88: 731-735$

Postbloom fruit drop (PFD) of citrus, caused by Colletotrichum acutatum, infects petals of citrus flowers and produces orange-brown lesions that induce the abscission of young fruitlets and the retention of calyces. Proper timing of fungicide applications is essential for good disease control. Different systems for timing of fungicide applications for control of PFD in a major citrusgrowing region in southern São Paulo state in Brazil were evaluated from 1999 to 2002. The following programs were compared to an unsprayed control using counts of diseased flowers, persistent calyces, or fruit: (i) a phenology-based program currently recommended in Brazil with one application at early and another at peak bloom; (ii) the Florida PFD model; (iii) the postbloom fruit drop-fungicide application decision system (PFD-FAD), a new computer-assisted decision method; and (iv) grower's choice. In 1999, no disease developed, sprays applied with the phenology-based program had no effect, and the Florida PFD model saved two sprays compared with the phenology-based program. In 2000, PFD was moderate and the phenology-based and growers' choice treatments had a significantly lower number of persistent calyces and higher fruit numbers than the control, but no differences were found between those treatments and the PFD model. In 2001, PFD was severe with considerable yield loss. The PFD model, the phenology-based program, and the grower's choice reduced flower blight and the number of persistent calyces, and improved fruit yields with two to three applications, but the PFD-FAD achieved comparable yields with only one spray. In 2002, the disease was mild, with no yield loss, and the Florida PFD model and the PFD-FAD saved one spray compared with the other systems. The PFD model and the PFD-FAD were equally effective for timing fungicide applications to control PFD in Brazil. Scouting of trees is simpler with PFD-FAD; therefore, this system is recommended and should eliminate unnecessary sprays and reduce costs for growers.
\end{abstract}

Postbloom fruit drop (PFD), caused by Colletotrichum acutatum Simmonds, produces orange-brown lesions on petals of citrus flowers and induces the abscission of fruitlets $(16,17)$. Persistent calyces from these flowers, commonly called buttons, which persist after fruit drop, remain for the life of the twig and are diagnostic for

Corresponding author: N. A. R. Peres

E-mail: naperes@ifas.ufl.edu

This study was supported by Fundação de Amparo a Pesquisa do Estado de São Paulo.

This research was supported in part by the Florida Agricultural Experiment Station and approved for publication as Journal Series R-09826.

A portion of the research was conducted while the senior author was located at the Instituto Biologico, São Paulo, SP, Brazil.

Current address of N. A. R. Peres: University of Florida, Gulf Coast Research and Education Center, Dover 33527.

Accepted for publication 15 March 2004.

Publication no. D-2004-0511-02R

(C) 2004 The American Phytopathological Society the disease. Conidia are produced in acervuli on infected petals and are dispersed by rain splash during the bloom period. Conidia deposited on leaves and other vegetative tissues germinate and form appressoria that serve as survival structures between flowering periods. When bloom begins the next season, appressoria of $C$. acutatum germinate and produce a few conidia on the leaf surface. These conidia are splashed onto the first flowers of the new season to continue the cycle $(1,22)$.

PFD was reported first in Belize in 1979 , and the pathogen now is distributed widely in the humid tropics of the Americas (4). The disease has important effects on yields, especially in areas where trees may flower at any time of the year, such as Central America, eastern Mexico, and the Caribbean (16). PFD first was reported in Brazil in 1979 (14), in Florida in 1983 (7), and causes sporadic yield losses when rains occur during the bloom period (11). In Brazil and in Florida, yield losses can vary from none to nearly $100 \%$ depending on inoculum availability and weather conditions during the bloom period $(11,21)$.

Early studies on control indicated that benomyl and captafol were the most effec- tive fungicides for control of the disease $(3,5)$. In Brazil, several benzimidazole and triazole fungicides, as well as mancozeb and folpet, are registered for control of PFD (2). In Florida, strobilurin fungicides and ferbam are registered (15). Benzimidazole fungicides alone or in combination have been highly effective for control of PFD in the field $(6,18)$.

A predictive model was developed in Florida for timing of fungicide applications. The model forecasts the percentage of flower infection 4 days in advance, considering the availability of inoculum and the amount of rainfall for the last 5 days. Temperature and relative humidity were not major factors, whereas the duration of leaf wetness had a small but significant effect on disease development (19). The Florida PFD model was evaluated for three consecutive years and a significant relationship was found between predicted and observed percentages of affected flowers. Fungicide applications timed according to the model reduced flower infection and the number of persistent calyces, and increased yields up to $500 \%$ compared with the nontreated control (21).

The Florida PFD model was modified subsequently to include the duration of leaf wetness following rainfall events (17), and it has been recommended in Florida to aid in timing for fungicide applications (15). Recommendations according to the model usually are effective in Florida, but the model occasionally can indicate sprays that are not necessary. In Brazil, fungicide applications have been recommended according to a program based on phenology of the bloom period (2).

A new system, the PFD-fungicide application decision system (PFD-FAD), was developed (9) to be more widely applicable in different citrus-producing regions and included risk factors such as the previous history of PFD in the grove, the susceptibility of the citrus variety, and the stage of the bloom, as well as the factors used in the PFD model (9). The PFD-FAD system was implemented in Java servlet, and it can be accessed at http://infotech.ifas.ufl.edu/ disc/pfd.

The purpose of this study was to compare the currently recommended flower phenology-based system, the Florida PFD Model, PFD-FAD, and grower's choice based on assessment of the bloom, rainfall, and disease situation for timing fungicide 
applications for control of PFD in a major citrus-growing region in southern São Paulo state in Brazil.

\section{MATERIALS AND METHODS}

Experiments were conducted from 1999 to 2002 in 5- to 11-year-old groves of Pera and Natal sweet oranges (Citrus sinensis (L.) Osb.), the cultivars grown in Brazil that are most susceptible to PFD, to compare systems for timing of fungicide applications. All plots used were located within 0.2 to $21 \mathrm{~km}$ of each other, near Itapetininga, São Paulo, Brazil. Plots of the different cultivars were not in the same location in all years. Fungicide applications according to the Florida PFD model (17) were compared with sprays applied according to a phenology-based program at early bloom and peak bloom, and according to the grower's assessment of the situation and the need for applications in all 4 years. In 2001 and 2002, the new PFD-FAD advisory system (9) was tested and compared with the above programs. There were two replications per treatment, each consisting of single rows of about 50 trees in six or seven locations. Treatments were arranged in a randomized complete block design with unsprayed guard trees between treated rows.

To determine the intensity and bloom stage required for the use of the Florida PFD model and the PFD-FAD, the percentage of pinhead, button bloom, and open flowers were estimated weekly in each location. The average percentage of button bloom and open flowers for all the plots were plotted as the percentage of flowers over the season. Leaf wetness data used for the forecasts were obtained from one Adcon weather station (Adcon Telemetry Addvantage Inc., Boca Raton, FL) centrally located in relation to the plots. Manual rain gauges placed at each location provided rain data for the disease forecasts. Fungicide applications were made with a Jacto Arbus 2000 sprayer at about 1,250 $\mathrm{kPa}$ using 780 liters/ha. The fungicides used and the dates of applications with each system in all the locations are presented in Table 1.

In December of each year, after the period of physiological fruit drop, three branches about $0.7 \mathrm{~m}$ long in each quadrant of the tree were used for counts of persistent calyces and fruit. Ten trees were selected arbitrarily in each treatment row for button and fruit counts. The data were expressed as the average number of persistent calyces and fruit on 12 branches per tree. In 2001 and 2002, the number of diseased flowers per tree was estimated weekly on 20 trees per treatment over the entire bloom period and the area under the curve (AUC) for the number of diseased flowers was calculated. The button and fruit count data for the 4 years and the AUC for diseased flowers in 2001 and 2002 were subjected to analysis of variance using locations as blocks with two replications in each. The means of the treatments were separated by the WallerDuncan $k$-ratio $t$ test $(P \leq 0.05)$.

\section{RESULTS}

In 1999, little rain fell during the entire bloom period and no disease developed (Fig. 1). The PFD model did not predict any sprays and the grower decided not to make any applications that year. The phenology-based treatment received two fungicide applications at early and peak bloom (Table 1). There was no increase in productivity when two sprays were applied according to the phenology-based program. Therefore, the PFD model was effective in indicating that no spray was necessary.

In 2000, bloom began late and developed very quickly (Fig. 1) due to high temperatures and few rain events. According to the Florida PFD model, there were two periods when the conditions were favorable for the disease. However, in the first period (1 to 5 September), there were only a few open flowers and no diseased flowers were present; therefore, no fungicides were applied as recommended by this model (17). The second period occurred between 13 and 16 September, and applications of benomyl were made in all plots of this treatment (Table 1). Two applications also were made, but at different times, according to the phenology-based program and the grower's choice treatment. The grower's choice treatment was applied during both periods when the con-

Table 1. Dates of the spray applications and the fungicides used to evaluate different systems for timing of sprays for control of postbloom fruit drop of citrus

\begin{tabular}{|c|c|c|c|c|c|c|c|c|c|c|c|c|c|}
\hline \multirow[b]{3}{*}{ Cultivar } & \multicolumn{13}{|c|}{ Spray date ${ }^{w}$} \\
\hline & \multirow{2}{*}{$\begin{array}{c}\text { 1999x }^{x} \\
\text { Phe }\end{array}$} & \multicolumn{4}{|c|}{$2000^{y}$} & \multicolumn{4}{|c|}{$2001^{z}$} & \multicolumn{4}{|c|}{$2002^{z}$} \\
\hline & & FL & Phe & GC & For & FL & Phe & GC & FAD & FL & Phe & GC & FAD \\
\hline \multirow[t]{3}{*}{ Pera 1} & $07 / 31$ & $09 / 15$ & $09 / 05$ & $09 / 05$ & $09 / 16$ & $07 / 26$ & 08/01 & $07 / 26$ & $08 / 24$ & $09 / 18$ & $08 / 27$ & $08 / 30$ & $09 / 09$ \\
\hline & $08 / 13$ & $\ldots$ & $09 / 18$ & $09 / 15$ & $09 / 22$ & $08 / 24$ & $08 / 16$ & $08 / 24$ & $\ldots$ & 09/04 & $09 / 16$ & $09 / 18$ & $\ldots$ \\
\hline & $\ldots$ & $\ldots$ & $\ldots$ & $\ldots$ & $\ldots$ & $\ldots$ & $\ldots$ & $08 / 29$ & $\ldots$ & $\ldots$ & $\ldots$ & $\ldots$ & $\ldots$ \\
\hline \multirow[t]{3}{*}{ Pera 2} & $07 / 30$ & $09 / 14$ & $09 / 03$ & $09 / 03$ & $09 / 16$ & $07 / 26$ & $08 / 13$ & $07 / 26$ & $08 / 24$ & $09 / 18$ & $08 / 27$ & $08 / 30$ & $09 / 18$ \\
\hline & $08 / 16$ & & $09 / 18$ & $09 / 14$ & $09 / 22$ & $08 / 24$ & $08 / 27$ & $08 / 24$ & $\ldots$ & $\ldots$ & $09 / 04$ & $09 / 16$ & $\ldots$ \\
\hline & $\ldots$ & $\ldots$ & $\ldots$ & $\ldots$ & $\ldots$ & $\ldots$ & $\ldots$ & $08 / 29$ & $\ldots$ & $\ldots$ & $\ldots$ & $\ldots$ & $\ldots$ \\
\hline \multirow[t]{3}{*}{ Pera 3} & $07 / 30$ & $09 / 18$ & $09 / 12$ & 09/07 & $09 / 16$ & $07 / 26$ & 08/07 & $07 / 26$ & $08 / 24$ & $09 / 18$ & $08 / 27$ & $08 / 30$ & $09 / 18$ \\
\hline & $08 / 17$ & $\ldots$ & $09 / 26$ & $09 / 12$ & $09 / 22$ & $08 / 24$ & $08 / 16$ & $08 / 24$ & $\ldots$ & $09 / 04$ & $09 / 16$ & & $\ldots$ \\
\hline & $\ldots$ & $\ldots$ & $\ldots$ & $\ldots$ & $\ldots$ & $\ldots$ & $\ldots$ & $08 / 29$ & $\ldots$ & $\ldots$ & $\ldots$ & $09 / 21$ & $\ldots$ \\
\hline \multirow[t]{3}{*}{ Pera 4} & ND & ND & ND & ND & ND & $07 / 27$ & $08 / 14$ & $07 / 27$ & $08 / 22$ & ND & ND & ND & ND \\
\hline & ND & ND & ND & ND & ND & $08 / 22$ & $08 / 29$ & $08 / 22$ & $\ldots$ & $\ldots$ & $\ldots$ & $\ldots$ & $\ldots$ \\
\hline & & $\ldots$ & $\ldots$ & $\ldots$ & & $\ldots$ & $\ldots$ & $08 / 29$ & $\ldots$ & $\ldots$ & $\ldots$ & & $\ldots$ \\
\hline \multirow[t]{2}{*}{ Pera 5} & ND & ND & ND & ND & ND & $07 / 30$ & $08 / 24$ & $07 / 27$ & $08 / 24$ & ND & ND & ND & ND \\
\hline & ND & ND & ND & ND & ND & $08 / 24$ & $09 / 01$ & $08 / 28$ & $\ldots$ & $\ldots$ & $\ldots$ & $\ldots$ & $\ldots$ \\
\hline \multirow[t]{3}{*}{ Natal 1} & $07 / 31$ & $09 / 15$ & $09 / 05$ & 09/05 & $09 / 16$ & $07 / 26$ & $08 / 13$ & $07 / 26$ & $08 / 24$ & $09 / 19$ & $08 / 27$ & $08 / 29$ & $09 / 19$ \\
\hline & $08 / 13$ & $\ldots$ & $09 / 18$ & $09 / 15$ & $09 / 22$ & $08 / 24$ & $08 / 29$ & $08 / 24$ & $\ldots$ & $\ldots$ & $09 / 04$ & $09 / 13$ & $\ldots$ \\
\hline & $\ldots$ & $\ldots$ & $\ldots$ & $\ldots$ & $\ldots$ & $\ldots$ & $\ldots$ & $08 / 29$ & $\ldots$ & $\ldots$ & $\ldots$ & $09 / 21$ & $\ldots$ \\
\hline \multirow[t]{3}{*}{ Natal 2} & $07 / 30$ & $09 / 15$ & 09/01 & $09 / 05$ & $09 / 16$ & $07 / 27$ & $08 / 24$ & $07 / 27$ & $08 / 24$ & $09 / 19$ & $08 / 27$ & $08 / 29$ & $09 / 19$ \\
\hline & $08 / 25$ & & $09 / 18$ & $09 / 15$ & $09 / 22$ & $08 / 24$ & 09/01 & $08 / 24$ & $\ldots$ & $\ldots$ & $09 / 04$ & $09 / 21$ & $\ldots$ \\
\hline & $\ldots$ & $\ldots$ & $\ldots$ & $\ldots$ & $\ldots$ & $\ldots$ & $\ldots$ & $08 / 29$ & $\ldots$ & $\ldots$ & $\ldots$ & $\ldots$ & $\ldots$ \\
\hline \multirow[t]{2}{*}{ Natal 3} & $07 / 30$ & $09 / 14$ & $09 / 03$ & $09 / 03$ & $09 / 16$ & ND & ND & ND & ND & $09 / 19$ & $08 / 27$ & $08 / 29$ & $09 / 19$ \\
\hline & $08 / 17$ & $\ldots$ & $09 / 18$ & $09 / 14$ & $09 / 22$ & $\ldots$ & $\ldots$ & $\ldots$ & $\ldots$ & $\ldots$ & $09 / 04$ & $09 / 13$ & $\ldots$ \\
\hline
\end{tabular}

${ }^{\mathrm{w}} \mathrm{Phe}=$ Phenology; FL = Florida postbloom fruit drop (PFD) model; GC = grower's choice; For $=$ rainfall forecast; FAD = PFD-fungicide application decision system, $\mathrm{ND}=$ not done.

${ }^{x}$ All treatments sprayed with benomyl (Benlate $500 \mathrm{PM}$ ) at $0.5 \mathrm{~g}$ a.i./liter + mancozeb (Dithane PM) at $1.2 \mathrm{~g}$ a.i./liter.

${ }^{\mathrm{y}}$ All treatments sprayed with benomyl (Benlate $500 \mathrm{PM}$ ) at $0.5 \mathrm{~g}$ a.i./liter as a tank mix.

${ }^{\mathrm{z}}$ All treatments sprayed with carbendazim (Derosal $500 \mathrm{SC}$ ) at $0.5 \mathrm{~g}$ a.i./liter. 
ditions were favorable for the disease according to the model. Neither the number of persistent calyces nor fruit numbers were significantly different between the Florida PFD model treatment with one spray, and the phenology-based and the grower's choice programs with two sprays each. The phenology-based and the grower's choice treatments, with two fungicide applications, had a significantly lower number of persistent calyces and higher numbers of fruit than the unsprayed control, but no differences were found between those treatments and the PFD model (Table 2). The Florida PFD Model forecast the fewest applications and saved one spray compared with the other forecasting systems without significantly reducing fruit number.

Bloom developed very slowly in 2001 (Fig. 1) due to unusually low temperatures in August, and the conditions were the most favorable for PFD occurrence among the 4 years of study. Three applications were made according to the grower's decision, two applications were made according to the Florida PFD model and phenology-based treatments, and one spray was applied according to the PFD-FAD system, which coincided with the second spray utilizing the Florida PFD model (Table 1). As indicated by the AUC for infected flowers, all sprayed treatments showed significantly fewer symptoms, more fruit, and fewer persistent calyces per tree compared with the unsprayed control. The growers' choice treatment with three sprays reduced the AUC more than the Florida PFD model or the PFD-FAD system, but did not significantly reduce the number of persistent calyces more than the other treatments. The PFD model with two sprays and the PFD-FAD with one spray reduced spray applications compared with the grower's choice program without affecting yield.

In 2002, bloom began during a period of severe drought and its intensity was very weak and not uniform (Fig. 1). One spray was triggered by both the PFD and PFDFAD models, except in one of the Pera plots that received two applications on the PFD-FAD treatment due to higher bloom intensity (Table 1). Two sprays were applied according the phenology-based program, and the grower's choice treatment entailed two to three sprays depending on the site. Comparing the AUC for blossom blight, disease incidence was much lower than in 2001. All spray treatments reduced

Table 2. Effect of different systems for timing of fungicide applications for control of postbloom fruit drop (PFD) on the area under the curve (AUC) for blossom blight, the number of persistent calyces, and the number of fruit ${ }^{\mathrm{w}}$

\begin{tabular}{|c|c|c|c|c|}
\hline Year, treatments ${ }^{x}$ & No. of sprays & $\mathbf{A U C} \mathbf{C}^{\mathbf{y}}$ & Persistent calyces $^{\mathrm{Z}}$ & Fruit \\
\hline \multicolumn{5}{|l|}{1999} \\
\hline Control & 0 & ND & 17 & 29 \\
\hline \multirow[t]{2}{*}{ Phe } & 2 & ND & 18 & 29 \\
\hline & & & NS & NS \\
\hline \multicolumn{5}{|l|}{2000} \\
\hline Control & 0 & ND & $62 \mathrm{a}$ & $21 \mathrm{~b}$ \\
\hline Phe & 2 & ND & $39 \mathrm{~b}$ & $27 \mathrm{a}$ \\
\hline GC & 2 & ND & $39 \mathrm{~b}$ & $30 \mathrm{a}$ \\
\hline FL & 1 & ND & $56 \mathrm{ab}$ & $25 \mathrm{ab}$ \\
\hline \multicolumn{5}{|l|}{2001} \\
\hline Control & 0 & $4,204 \mathrm{a}$ & $90 \mathrm{a}$ & $24 \mathrm{~b}$ \\
\hline Phe & 2 & $707 \mathrm{~cd}$ & $46 \mathrm{~b}$ & $30 \mathrm{a}$ \\
\hline GC & 3 & $618 c$ & $46 \mathrm{~b}$ & $31 \mathrm{a}$ \\
\hline FL & 2 & $1,211 \mathrm{c}$ & $45 \mathrm{~b}$ & $33 \mathrm{a}$ \\
\hline FAD & 1 & $2,138 \mathrm{~b}$ & $54 \mathrm{~b}$ & $29 \mathrm{a}$ \\
\hline \multicolumn{5}{|l|}{2002} \\
\hline Control & 0 & $150 \mathrm{a}$ & $25 \mathrm{c}$ & 14 \\
\hline Phe & 2 & $7 \mathrm{c}$ & $16 \mathrm{~d}$ & 15 \\
\hline $\mathrm{GC}$ & $2-3$ & $6 \mathrm{c}$ & $24 \mathrm{c}$ & 14 \\
\hline FL & 1 & $130 \mathrm{~b}$ & $42 \mathrm{a}$ & 13 \\
\hline \multirow[t]{2}{*}{ FAD } & $1-2$ & $115 \mathrm{~b}$ & $33 \mathrm{~b}$ & 14 \\
\hline & $\ldots$ & $\cdots$ & $\ldots$ & NS \\
\hline
\end{tabular}

${ }^{\mathrm{w}}$ Values followed by the same letter are not significantly different $(P>0.05)$ based on the WallerDuncan $k$-ratio $t$ test; NS $=$ not significant, ND $=$ not determined.

${ }^{\times}$Control $=$unsprayed control, $\mathrm{Phe}=$ phenology-based program, $\mathrm{GC}=$ grower's choice, $\mathrm{FL}=$ Florida PFD model, FAD = PFD-fungicide application decision system.

${ }^{y}$ Area under the curve for the number of diseased flowers.

${ }^{\mathrm{z}}$ Average number of persistent calyces or fruit on 12 branches per tree; average of 20 trees per location.


Fig. 1. Bloom stage and rainfall distribution from 1999 to 2002. Line graph $=$ average percentage of button bloom and open flowers in planting. Vertical bars $=$ total daily rainfall in $\mathrm{mm}$. 
the number of diseased flowers compared with the unsprayed control (Table 2). The grower's choice and phenology-based treatments, which received at least two sprays, were more efficient than the models in reducing disease incidence and the number of persistent calyces. However, the number of persistent calyces in the control was intermediate between the other treatments. None of the treatments increased fruit counts. No applications would have been necessary for PFD control; therefore, the Florida PFD model and PFD-FAD forecast would have been least costly because they recommended only one or, at most, two sprays.

\section{DISCUSSION}

The PFD model and the PFD-FAD were effective for avoiding sprays that were not necessary when the conditions are not favorable for disease development. The use of the PFD model and the PFD-FAD helped to avoid sprays in 3 of the 4 years compared with the phenology-based spray program that is usually recommended in Brazil (2), and also saved sprays compared with the decisions of a grower who is very experienced in dealing with the disease. The growers' choice and phenology-based program in one case resulted in significant yield increases that were not observed with the models, but yields with these programs were significantly better than with the models.

PFD incidence can vary greatly according to the weather conditions in each year. If no rain falls over the entire bloom season, no disease occurs, as was observed in 1999. However, if the conditions are favorable, inoculum can build up very quickly and disease can cause significant yield losses as observed in 2001. In 2000, disease level was low to moderate and the use of the PFD model saved one spray compared to the other treatments without affecting yield. When testing the PFD model in Florida, Timmer and Zitko (21) found that predictions usually were more accurate when disease levels were low to moderate. Their results showed an increase in the number of fruit up to $500 \%$, compared with $200 \%$ in our studies. Although disease appeared in 3 of the 4 years of the study, the severity was not as intense as in Florida, nor was it as severe as observed in 1996 on the same farm in which the present studies were conducted, where yield losses were up to $80 \%$ (N. A. R. Peres, unpublished information).

Yield losses are observed only when conditions for disease are severe; therefore, some of the sprays applied according to the phenology-based program could be avoided. However, when bloom is extended and weak, disease control is more difficult and the phenology-based spray program may provide better protection of the flowers if sprays coincide with favorable conditions for disease, as observed in
2002. Because disease development is explosive, spray timing is very important to achieve good disease control. Applications of benomyl on flower clusters have been shown to reduce symptom development by $75 \%$ when sprayed $24 \mathrm{~h}$ before and up to $48 \mathrm{~h}$ after inoculation (12). Thus, fungicides must be applied within $72 \mathrm{~h}$ after the beginning of a rain event when inoculum is present.

The amount of bloom infection does not always correspond to yield losses because only a small percentage of the bloom sets fruit, and growers sometimes can overestimate disease severity. In Florida, it was estimated that about six fruit are lost for each 100 persistent calyces formed (20). In our studies, we found a very similar relationship (data not presented). No differences in the number of persistent calyces or fruit were found among the different spray programs in 2001, and the grower could have saved one or two sprays if one of the models had been used. Application costs vary considerably from country to country depending on labor, equipment, and fungicide costs; therefore, the value of saving one fungicide spray is dependent on these factors as well as the value of the fruit. We have dealt with the economic effects of PFD and the cost of control measures in other publications $(8,10,13,21)$. In this case, the grower had a good understanding of the disease and usually sprayed after every rain event that would promote disease development. Spray costs in Brazil can be one third of those in Florida due to much lower labor expenses $(8,9)$. With the spray conditions used in our experiments and the economic situation in Brazil, an increase of only 12 fruit per tree was sufficient to pay for the three sprays applied by the grower in 2001 . Because the cost of fungicide applications is low, growers tend to be conservative and try to eliminate any risk of yield loss. Thus, growers should take advantage of the models to reduce spray costs, but also may wish to use their own judgment and consider spray costs, the price of the fruit, and the amount of risk they are willing to accept. However, the models tend to be conservative and are more likely to recommend sprays that are not necessary than to fail to forecast a necessary application.

The PFD-FAD system was developed based on the PFD model to be more widely applicable to different regions by including such factors as stage of bloom, occurrence of multiple blooms, history of PFD in the grove, and varietal susceptibility. The system is simpler to use and minimizes the acquisition of exact weather information and the need for intense scouting. Both the PFD model and the PFD-FAD seem to be especially useful to indicate when sprays are not necessary. However, the PFD model seems to be slightly more conservative than the PFD-FAD and, occasionally, an application that would not be required by the PFD-FAD may be recommended, as was observed in 2002. The PFD-FAD also can help the growers to have a better understanding of the disease by using the system, and it also allows them to introduce their own judgment based on economic factors.

\section{ACKNOWLEDGMENTS}

This study was supported by Fundação de Amparo a Pesquisa do Estado de São Paulo. We thank Citrovita Agrícola Ltda, especially M. Dinardo and E. Lopes, and R. F. da Silva for assistance on conducting the experiments.

\section{LITERATURE CITED}

1. Agostini, J. P., and Timmer, L. W. 1994. Population dynamics and survival of strains of $\mathrm{Col}$ letotrichum gloeosporioides on citrus in Florida. Phytopathology 84:420-425.

2. Compêndio de defensivos agrícolas: guia prático de produtos fitossanitários para uso agrícola. 1999. 6 ed. Organização Andrei Editora, São Paulo, SP, Brazil.

3. Denham, T. G. 1979. Citrus production and premature fruit drop disease in Belize. PANS 25:30-36.

4. Fagan, H. J. 1979. Postbloom fruit drop, a new disease of citrus associated with a form of $\mathrm{Col}$ letotrichum gloeosporioides. Ann. Appl. Biol. 91:13-20.

5. Fagan, H. J. 1984. Postbloom fruit drop of citrus in Belize: II. Disease control by aerial/ground spraying. Turrialba 34:179-186.

6. Goes, A., Moretto, K. C. K., and de Wit, C. van P. 2003. Effect of ferbam alone or in combination with benomyl for the control of citrus postbloom fruit drop. Proc. IX Int. Soc. Citricult. 2000:1003-1005.

7. McMillan, R. T., and Timmer, L. W. 1989. Outbreak of citrus postbloom fruit drop caused by Colletotrichum gloeosporioides in Florida. Plant Dis. 73:81.

8. Peres, N. A. R. 2002. Modelo de previsão e controle da podridão floral dos citros causada por Colletotrichum acutatum. Ph.D. diss. Universidade Estadual Paulista, Faculdade de Ciências Agronômicas, Botucatu, SP, Brazil.

9. Peres, N. A. R., Kim, S., Beck, H. W., Souza, N. L., and Timmer, L. W. 2002. A fungicide application decision (FAD) support system for postbloom fruit drop of citrus (PFD). Online. Plant Health Progress doi: 10.1094 PHP-20020731-01-RV.

10. Peres, N. A. R., Kim, S., Beck, H. W., and Timmer, L. W. 2002. PFD-FAD, a new system of fungicide sprays for control of postbloom fruit drop. Citrus Veg. Mag. 67(4):28-30.

11. Peres, N. A. R., Souza, N. L., and Timmer, L. W. 2003. Postbloom fruit drop in Brazil and Florida: occurrence and control by fungicides. Proc. IX Int. Soc. Citricult. 2000:1051-1052.

12. Peres, N. A. R., Souza, N. L., Zitko, S. E., and Timmer, L. W. 2002. Activity of benomyl for control of postbloom fruit drop of citrus caused by Colletotrichum acutatum. Plant Dis. 86:620-624.

13. Peres, N. A. R., and Timmer, L. W. 2003. PFD-FAD: Um novo sistema de previsão para o controle da podridão floral. Citricult. Atual 35:10-11

14. Porto, O. M., Rossetti, V., and Dornelles, C. M. M. 1979. Queda de frutos jovens de citros, causada por Colletotrichum sp. no Rio Grande do Sul. An. Congr. Brasil. Fruticult. 5:681-692.

15. Timmer, L. W., ed. 2003. 2003 Florida Citrus Pest Management Guide. Univ. Florida Coop. Ext. Serv., Univ. Florida, Gainesville. Publ. No. SP-43.

16. Timmer, L. W., Agostini, J. P., Zitko, S. E., and Zulfiqar, M. 1994. Postbloom fruit drop of citrus, an increasingly prevalent disease of citrus 
in the Americas. Plant Dis. 78:329-334.

17. Timmer, L. W., and Brown, G. E. 2000. Biology and control of anthracnose diseases of citrus. Pages 300-316 in: Host Specificity, Pathology, and Host-Pathogen Interactions of Colletotrichum. D. Prusky, S. Freeman, and M. B. Dickman, eds. American Phytopathological Society Press, St. Paul, MN.

18. Timmer, L. W., and Zitko, S. E. 1992. Timing of fungicide applications for control of postbloom fruit drop of citrus in Florida. Plant Dis. 76:820-823.

19. Timmer, L. W., and Zitko, S. E. 1993. Relationships of environmental factors and inoculum levels to the incidence of postbloom fruit drop of citrus. Plant Dis. 77:501-504.

20. Timmer, L. W., and Zitko, S. E. 1995. Early season indicators of postbloom fruit drop of citrus and the relationship of disease incidence and fruit production. Plant Dis. 79:1017-1020.

21. Timmer, L. W., and Zitko, S. E. 1996. Evaluation of a model for prediction of postbloom fruit drop of citrus. Plant Dis. 80:38-383.

22. Zulfiqar, M., Brlansky, R. H., and Timmer, L. W. 1996. Infection of flower and vegetative tissues of citrus by Colletotrichum acutatum and C. gloeosporioides. Mycologia 88:121-128. 